\title{
The richness of plants in Art Nouveau gardens
}

\author{
Krystyna Pudelska*, Anna Mirosław \\ Department of Ornamental Plants and Landscape Architecture, University of Life Sciences in Lublin, Głęboka 28, 20-612 Lublin, Poland
}

\begin{abstract}
The turn of the 19th and the 20th centuries signified the appearance of a new trend in art called Art Nouveau in England, Stile floreale in Italy, and in Poland - secesja. It was an attempt to escape from the style that copied historical forms and set a new direction of development. The main inspiration for the creators of this period became nature, its asymmetry, variety of textures, subtle colors or smooth, and wavy lines. Artistic motifs were drawn from the richness of native flora and fauna. Flowering shrubs, perennials and creepers were especially inseparable decorative and compositional elements of a garden.

Secession had a significant impact on painting, sculpture, architecture, and garden design. The space surrounding people was treated comprehensively by blurring the boundaries between different arts. A multitude of shrubs - especially roses and lots of perennials such as Lilium, Iris, and Phlox, gave the impression of architecture immersing in the surrounding garden.

The aim of the paper was to briefly analyze the Art Nouveau style and present the diversity of species used in the gardens of that period.
\end{abstract}

Keywords: Art Nouveau; floral motifs; species of plants; gardens

\section{Introduction}

In the history of the European and American art, the turn of 19th and the beginning of the 20th centuries was the arrival of a new style. It appeared in the $80 \mathrm{~s}$ of the19th century out of a desire to break with the existing stylistics and create something new and unique. The years 1890-1910 are considered to be the period of its full flourish [1]. This trend developed in many countries at the same time and was known under various names. In England a popular term was Art Nouveau or The New Style, The Wavy Line or The Neo-Floral Style. Similarly, in France the new direction of artistic activities was called Art Nouveau, "Modern style", while in Austria Sezessionsstil or Sezession. Poland, the Czech Republic and Slovakia adopted the transformed Austrian name - Secession. All of the names emphasized the diversity of the newly formed art and captured its main features [2].

What distinguished Art Nouveau were its decorative qualities, linear style [3] and a flowing, wavy and organically shaped line inspired by nature. The typical aim was to obtain slim, lightweight shapes, emphasizing the asymmetry and verticalism. Vivid, saturated colors used in the previous years were replaced with gentle pastel tones [2-5]. European artists were inspired by the features of Far Eastern aesthetics, e.g. the asymmetric composition that gave a dynamic character to a work of art.

\footnotetext{
* Corresponding author. Email: krystyna.pudelska@up.lublin.p
}

Handling Editor: Elżbieta Weryszko-Chmielewska
The world leading representatives of Art Nouveau artists were Henri de Toulouse-Lautrec, Louis Comfort Tiffany, Gustave Klimt, Alfons Mucha [6] and the architects Victor Horta Joseph Maria Olbrich, Otto Wagner, and Hector Guimard [7]. A remarkable contribution to the popularization of the new trend was made by Antonio Gaudi whose buildings (Casa Batllo, Casa Mila, Sagrada Familia in Barcelona), through the organic shape of facades and decorative elements, became the world's most recognizable symbol of Secession [8]. In Poland appreciated creators included Józef Mehoffer or Stanisław Wyspiański.

The new style moves from painting and decorative art to architecture [2] and gardening art. Due to the short duration of Art Nouveau, it did not establish its influences in horticulture and the creation of specific arrangements [9]. The gardening art of that time stood out mainly because of directing its interest towards nature. The great number of available plants was the result of a widening knowledge of botany, allowing acclimatization of exotic species, imported from, e.g. China or Japan, and rediscovering the diverse world of species so far considered to be common ones, e.g. flowering or meadow plants.

\section{Aim and material}

The main aim of the present article is to discuss the Art Nouveau stylistics of one of the styles in the European art which influenced the arrangement of the Secession park. The essence of the study is to present the specific species of Secession gardens which developed from the end of the 19th century until 1914. Apart from the simplicity, practicality 
and functionality, they also emphasized the variety of plants, especially creepers and perennials. The issues presented in this review article are based on the relevant literature, iconography and cartography. The spatial range concerns the examples from European countries, including Poland.

\section{Plant motifs in art}

Many ornamental plants fully reflected the main lines of the new artistic style and were an important source of inspiration. Trees, perennials, bulbs and so far underestimated herbaceous plants, their stems, leaves, inflorescences and fruit, had an important place among the most widely used motifs. Plants, animals and human beings, apart from the direct, decorative meaning, in most works of art had a symbolic meaning and they were interpreted individually.

One of favorite tree species was Aesculus hippocastanum. Due to the characteristic structure of its leaves, which consists of 5 to 7 obovate leaflets and the pyramidal inflorescence, it was readily planted in the gardens of the turn of the century and used as a decorative theme. It appeared on facades, metalwork (the staircase balustrade designed by Wyspiański, 4 Radziwiłłowska Street, Kraków), murals (the villa at 31/33 Wólczańska Street, Łódź), painting, and applied arts. Many Art Nouveau buildings were decorated with elements in the shape of various tree species, e.g. Quercus robur [the building facade at 17 Narutowicza Street or 9 Szopena Street in Lublin (Fig. 1)].

Equally popular was Tropaeolum majus with its flexible, procumbent stem, characteristic oval leaves, and delicate flowers. Thanks to these features, it gained importance, despite the fact that it had been cultivated in the gardens since the 17th century. In the company of Iris, Lilium and Helianthus, it appears on murals (the house at 3 Maja Street in Lublin), as part of the facades of numerous buildings (e.g. 70 Grunwalda Street, Sopot). Papaver rhoeas (similar to Tropaeolum in its slenderness and softness) was also frequently used as a decorative element (Fig. 2).

Rosa and Lilium won great popularity due to their decorative qualities and various symbolic meanings. These motifs appear in painting and drawing (armfuls of flowers consisting of Rosa, Lilium, Papaver, Iris, Dianthus, and Campanula are present in posters and a series of large-format canvas by Alfons Mucha), in applied arts (a part of the fencing in Schopp Villa in Vienna, Austria), and architecture (Helianthus, Lilium, Rosa, Tulipa, and Papaver decorate the Art Nouveau buildings at 3 Maja Street; Fig. 2-Fig. 4).

Iris was an equally popular theme in Art Nouveau. Its erected stems and leaves as well as original flowers decorate many buildings (e.g. the house at 17 Wielkie Garbary Street in Toruń, or at 10 Jagiellońska Street in Bydgoszcz) and everyday objects. They appear in paintings and drawings. Iris can be found in Art Nouveau polychromies and stained glass windows by Stanisław Wyspiański, decorating the chancel and transept of the Franciscan church in Kraków [10]. In Lublin what draws attention is a large number of buildings decorated with a sunflower motif, which as Iris represented verticalism of interior doors [e.g. staircase railings or tenements at 12 and 14 Okopowa Street, 103 Maja Street, 12 Szopena Street, 57 Krakowskie Przedmieście Street (Fig. 3)].

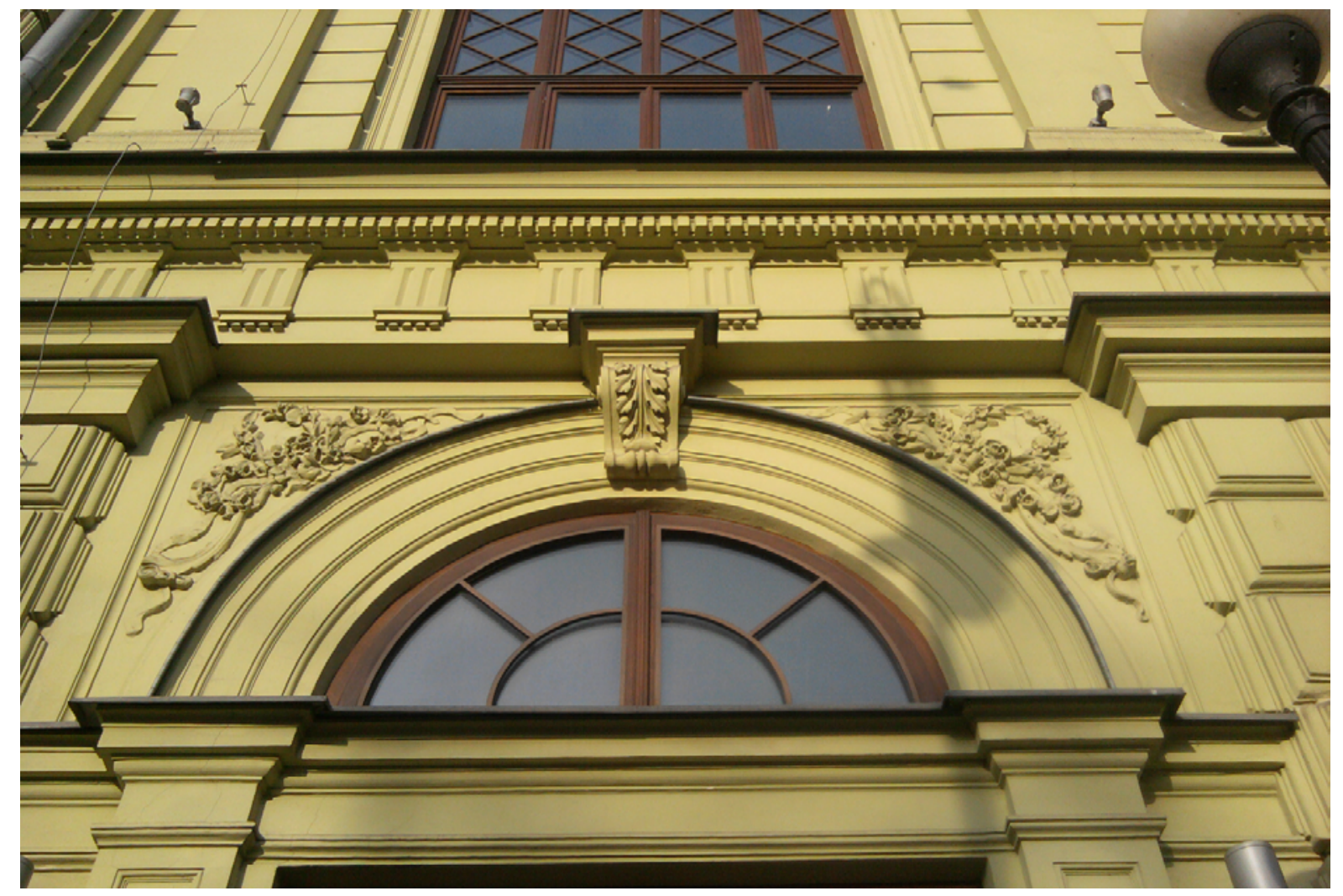

Fig. 1 Oak leaf motif, building at 17 Narutowicza Street in Lublin, phot. A. Mirosław. 


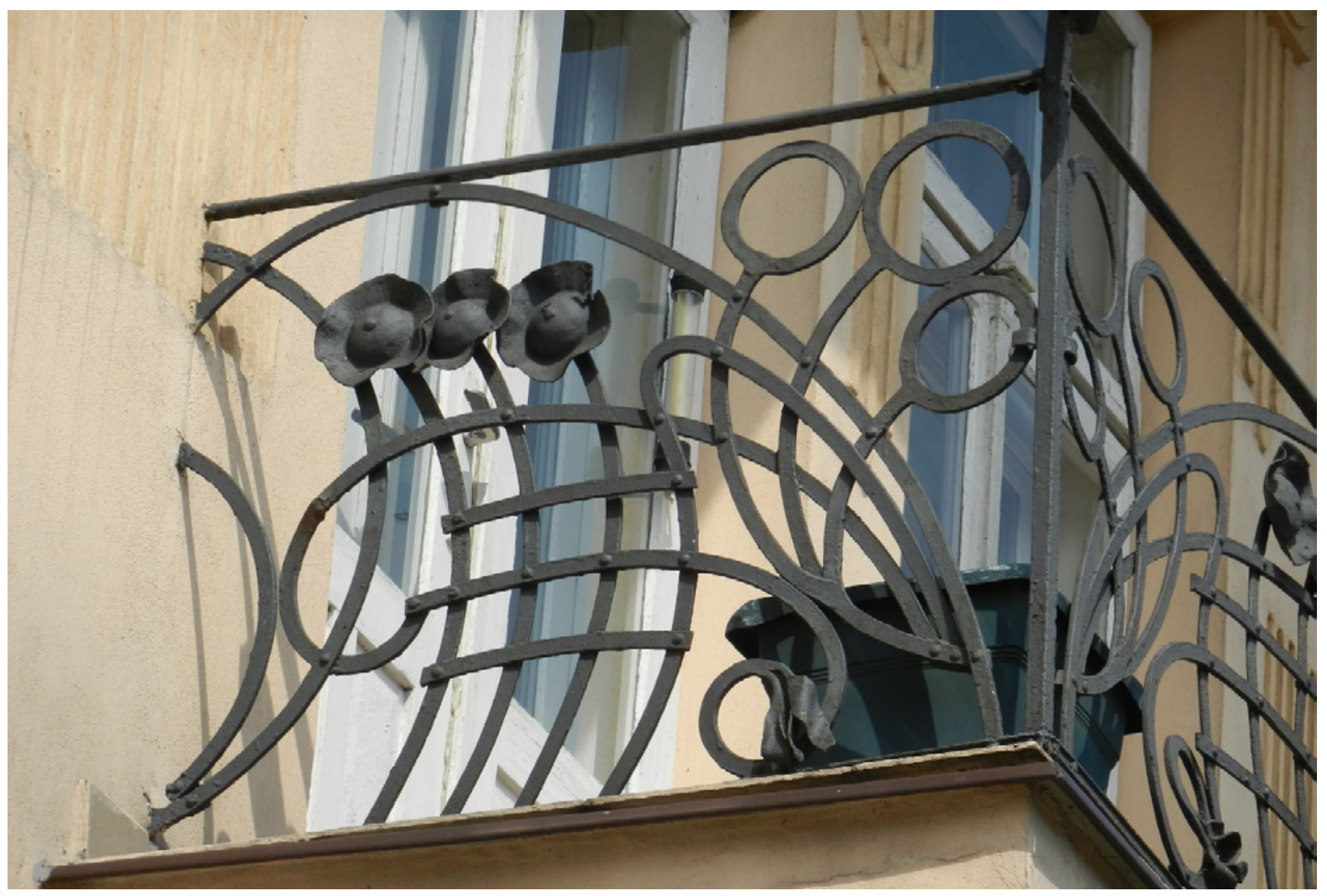

Fig. 2 Balcony balustrade with the common poppy motif. Art Nouveau building at 3 Maja Street, phot. K. Rojek.

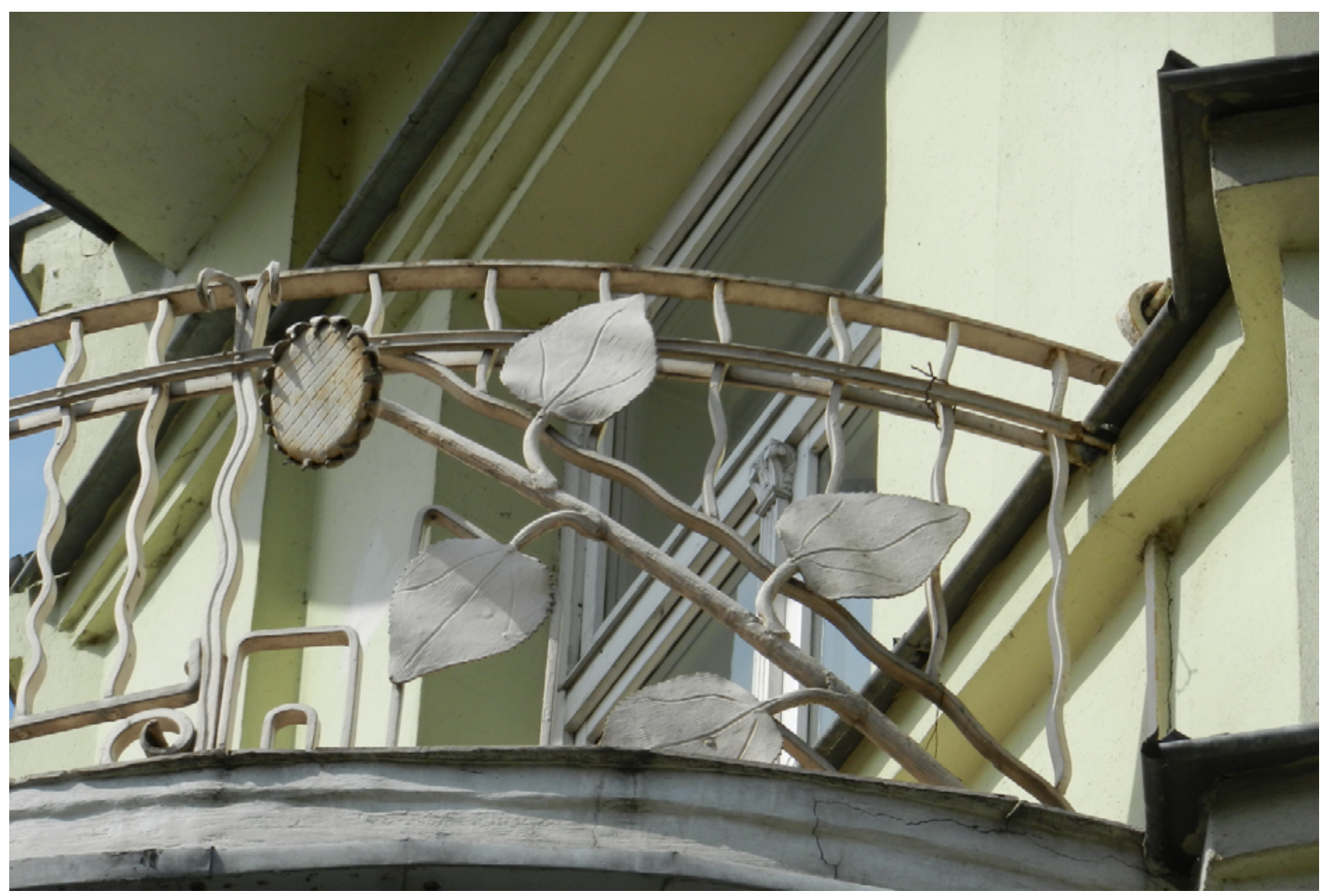

Fig. 3 Balcony balustrade with the sunflower motif, 123 Maja Street in Lublin, phot. K. Rojek. 


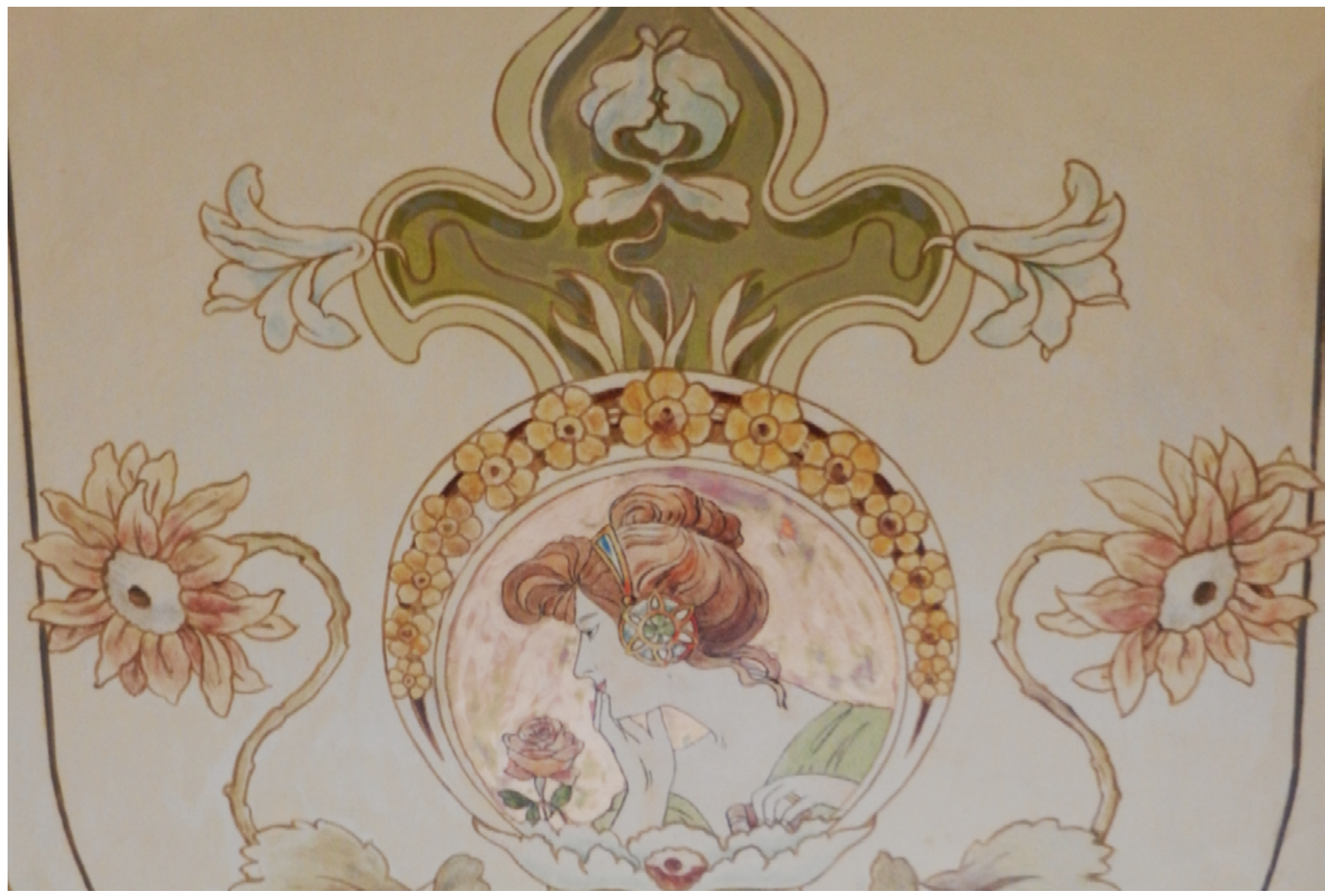

Fig. 4 Fragment of a ceiling decorated with sunflowers, lilies, irises, Art Nouveau building at 63 Maja Street, phot. K. Rojek.

\section{Secession elements and motifs of gardens at the turn of the 19th and the 20th centuries}

The Secession garden "comprises mainly of Secession elements and motifs, it rarely constitutes a holistic spatial system" [1]. The main element of the composition is a line, mostly long, flexible, twinning, giving impression of the plant's growth, because as Secessionists claimed it reflected life $[2,4]$. Such a natural shape was marked by roads, paths, river banks, water, hedges, constructions, or borders of plants. Their sigmoid, parabolic shape symbolized freedom and made the composition look light.

However, vertical lines emphasized by high trees, towering plants' stems, walls, constructions of trellis and pergolas were to show the growth and climbing of plants. Towering long stems, such as in foxglove, iris, lilies and sunflowers, reflected the love of Secession artists for verticalism. However, some of the species, those with flexible stems moving in the wind (e.g. cane - Phragmites australis, a popular water plant in Secession), were eagerly used in the arrangement of the garden. Their slender stems moving in the wind symbolized the changeability of life.

Secession art used organic motifs, i.e. decorative elements (plants, animals or anthropomorphic elements; Tab. 1). The most frequently used were the decorations based on smooth plant patterns. Apart from flora, the animal world was equally interesting. Special attention was paid to insects, birds, small amphibians or reptiles. Butterflies, dragonflies, grasshoppers, swans or flamingos were the main source of colors and decorations [2,3].
The free arrangement of the Secession garden, inspired by Far Eastern art (asymmetric composition, motifs from nature) consists of interiors with large planes of organic shapes, different textures of the plant material or aggregate and permeating colors. Favorite species of pastel colors dominate. The creators of gardens - architects, landscape architects or gardeners, eagerly used flora familiar to them (Willy Lange, Karl Foerster, Frederick Law Olmsted, John Muir, Jens Jensen, Warren Manning or Andrew Downing). The native species were popular both in village gardens (sunflower, carnation) and in fields and meadows (milkweed, poppy, thistle, species from the Nymphaeaceae or Typhaceae family), but foreign species were also suggested (e.g. palms, nasturtium). Antonio Gaudi or William Robinson advised to plant not only native species but also "exotic flowers". The shape of plants following the rules of the new artistic trend was important. Flowers of radial symmetry (sunflower, thistle, field rose), bilaterally symmetrical (cyclamen, pansy, plants from the Fabaceae or Lamiaceae family), or asymmetrical (Calla) [2]. The garden with Secession motifs was full of different senses - eyesight, touch or smell, which allowed one to have close contact with nature.

\section{Greenery of Art Nouveau gardens}

Art Nouveau gardens were usually confined to small areas, where a building and the surrounding lush vegetation blended well. Often it took the form of a winter garden or "flowery loggias" [11]. The new style manifested itself 
Tab. 1 Basic elements, floral and animal motifs in Secession gardens and their meanings $[2,16,29-33]$.

\begin{tabular}{lll}
$\begin{array}{l}\text { Element, animal } \\
\text { and plant motif }\end{array}$ & Symbols & Reference \\
\hline $\begin{array}{l}\text { line (twinning, } \\
\text { straight) }\end{array}$ & fluency, changeability, movement in nature & {$[2,16,29]$} \\
asymmetry & longevity, persistence & {$[2,29]$} \\
tree & $\begin{array}{l}\text { symbol of space, life, youth, immortality, worship of Mother Earth } \\
\text { and abundance }\end{array}$ & {$[2,16,30]$} \\
Lilium & purity, innocence, virginity, resurrection, and God's providence & {$[2,30,31]$} \\
Calla & femininity & {$[29]$} \\
Dianthus & symbol of marriage, promise of love & {$[30]$} \\
Helianthus & affection, symbol of the sun & {$[16]$} \\
Iris & $\begin{array}{l}\text { symbol of the virgin birth, attribute of Virgin Mary, } \\
\text { the sabre-shaped leaf means suffering, grief }\end{array}$ & {$[2,29]$} \\
Papaver & $\begin{array}{l}\text { symbol of night, sleep, dreams, it means death but also sacrifice, } \\
\text { vanishing }\end{array}$ & {$[31,32]$} \\
Rosa & love, memory & \\
butterfly & resurrection, salvation, symbol of soul, happiness, change & {$[30,33]$} \\
dragonfly & infinity, regeneration, activity, richness of colors - permanent change & {$[33]$} \\
swan & perfection, beauty, purity, nobility, dignity but also sadness & {$[33]$} \\
peacock & $\begin{array}{l}\text { immortality, glory, but also the incarnation of the sun and } \\
\text { illumination }\end{array}$ & {$[16,30,33]$} \\
\hline
\end{tabular}

mostly in newly created urban spaces and suburban villas. Despite the small space, gardens were characterized by a large number of various species of vines, perennials, trees, and shrubs $[9,12-14]$.

\section{Vines}

In gardening art, plants characterized by a wavy, sigmoidal structure of stems gained a great respect $[2,15]$. Especially creepers such as Convolvulus, Parthenocissus, Wisteria, Vitis, and Hedera perfectly reflected the main ideas of the new trend $[5,16]$. Twining around supports, forming twisted tendrils, thanks to which they climbed upwards, these plants were the essence of Art Nouveau. They were used to cover various structures, spread on arbors, pergolas or on the walls of buildings. The species that appeared in Poland in the mid-nineteenth and the early twentieth centuries came from North America, China, Japan and the Korean Peninsula, inter alia Vitis riparia, Wisteria floribunda or Actinidia kolomikta (Tab. 2) [17].

Nowadays, the richness of vines can be easily seen in the decorative motifs and the preserved gardens of that period. Numerous villas, part of the Art Nouveau housing estate

Tab. 2 Species characteristic of Art Nouveau [2,17].

\begin{tabular}{|c|c|c|c|}
\hline $\begin{array}{l}\text { Species of creepers } \\
\text { introduced in Polish } \\
\text { gardens in the mid-19th and } \\
\text { beginning of 20th century }\end{array}$ & $\begin{array}{l}\text { Species representing } \\
\text { verticalism }\end{array}$ & $\begin{array}{l}\text { Species with symmetrical } \\
\text { form }\end{array}$ & $\begin{array}{l}\text { Species linked with the Far } \\
\text { Eastern art }\end{array}$ \\
\hline $\begin{array}{l}\text { Actinidia arguta } \\
\text { Planch. ex Miq. }\end{array}$ & Digitalis purpurea L. & Carduus crispus L. & $\begin{array}{l}\text { Chrysanthemum } \\
\text { ×grandiflorum Ramat. }\end{array}$ \\
\hline Actinidia kolomikta Maxim. & Gladiolus $\times$ gandavensis & Cytisus scoparius $\mathrm{L}$. & $\begin{array}{l}\text { Chrysanthemum coreanum } \mathrm{H} \text {. } \\
\text { Lev. et Vaniot }\end{array}$ \\
\hline Aristolochia macrophylla Lam. & Iris germanica L. & Iris germanica L. & Lilium regale $\mathrm{L}$. \\
\hline Campsis radicans (L.) Seem. & Lilium candidum $\mathrm{L}$. & Lamium album L. & Narcissus poeticus L. \\
\hline Polygonum aubertii L. & Phragmites australis Cav. & Rosa canina L. & Nuphar lutea L. \\
\hline Vitis riparia Michx. & Scirpus sylvaticus L. & Tropaeolum majus L. & Paeonia lactiflora Pall. \\
\hline Wisteria floribunda Dc. & Verbascum phoeniceum L. & Viola tricolor L. & Magnolia kobus DC. \\
\hline
\end{tabular}


Salwator in Kraków, are "embedded" in greenery. Buildings, fences and even trees are covered with Parthenocissus quinquefolia, Hedera, Fallopia baldschuanica, or Vitis (Fig. 5). In a dense urban area, a limited space as well as the fascination with creepers led to the creation of vertical gardens, an example of which is the "Pod Pająkiem" bulding in Kraków. A minimalist composition was created by special niches in the walls where plants could grow, which was to link the building with its surrounding space [18].

\section{Perennials}

William Robinson had a significant impact on the character of plantings in Art Nouveau gardens. In his books The Wild Garden (1870) and The English Flower Garden (1983), this Irish gardener and writer popularized at the end of the nineteenth century a wide range of plants in compositions of a more natural look. Moreover, he advocated the use of native species as well as exotic plants, carefully selected according to their habitat. He created the concept of "a wild garden" in which flowering perennials, bulbs, and tubers, such as Narcissus, Galanthus nivalis, Anemone, and Crocus, played an important role [13]. The planting schemes in a garden in Bexleyheath (now south-east London) reflect the trends in English gardening of that time - the garden and the house form an integral unit. The former mansion of William Morris, one of the major contributors to the English Arts and Crafts movement (who had a great impact on Secession gardens in Europe), is an example of the new trend [19]. There one can find plenty of species from different groups: trees, shrubs, and especially perennial plants. Along with the design for a building, a concept of linking the particular architecture with its surrounding space was successfully developed. The main goal of the design was to create walls covered with vines such as Jasminum, Lonicera and climbing roses, which would harmonize with a brick facade and unite the house with the garden. "Green rooms" of a garden, following the rules of the contemporary designers, i.e. Gertrude Jekyll and Willy Lange, were marked out by hedges, trees, and grassy paths. In the garden there were apple trees growing - a remnant of the old orchard - along with Lavandula, Rosmarinus, Helianthus, and Lilium [19]. The garden was connected with the house through a flowered terrace, flowered constructions, a winter garden or the flowerbeds. It was to give an impression of a more spacious building and architecture, and the formal arrangement of the garden was filled with mixed plants, bushes, perennials, annual plants, and often with self-seedlings. Plants blurred the lines of strongly marked forms.

English gardens of Gertrude Jekyll or American gardens of Beatrix Farrand are the examples of introducing lush "mix" of plants, mostly perennials, of different textures of leaves, flowers or tree bark. These pictorial arrangements interacted in the harmony of colors and values of plants. The effect of picturesqueness and the naturalness of composition was the result of very good knowledge of plants, their structure, preferences and habitat conditions as well as the ability to use the right color [13].

Among plants, those with high straight stems, which were well suited to the trend to create vertical arrangements, held a distinctive place. Gertrude Jekyll's favorites were Alcea and Delphinium. The gardens were eagerly planted with Gladiolus, Digitalis, Verbascum, and Iris. Species with bilaterally symmetric flowers [2,20], for example Viola tricolor, Lamium album and Cytisus, attracted growing attention and interest.

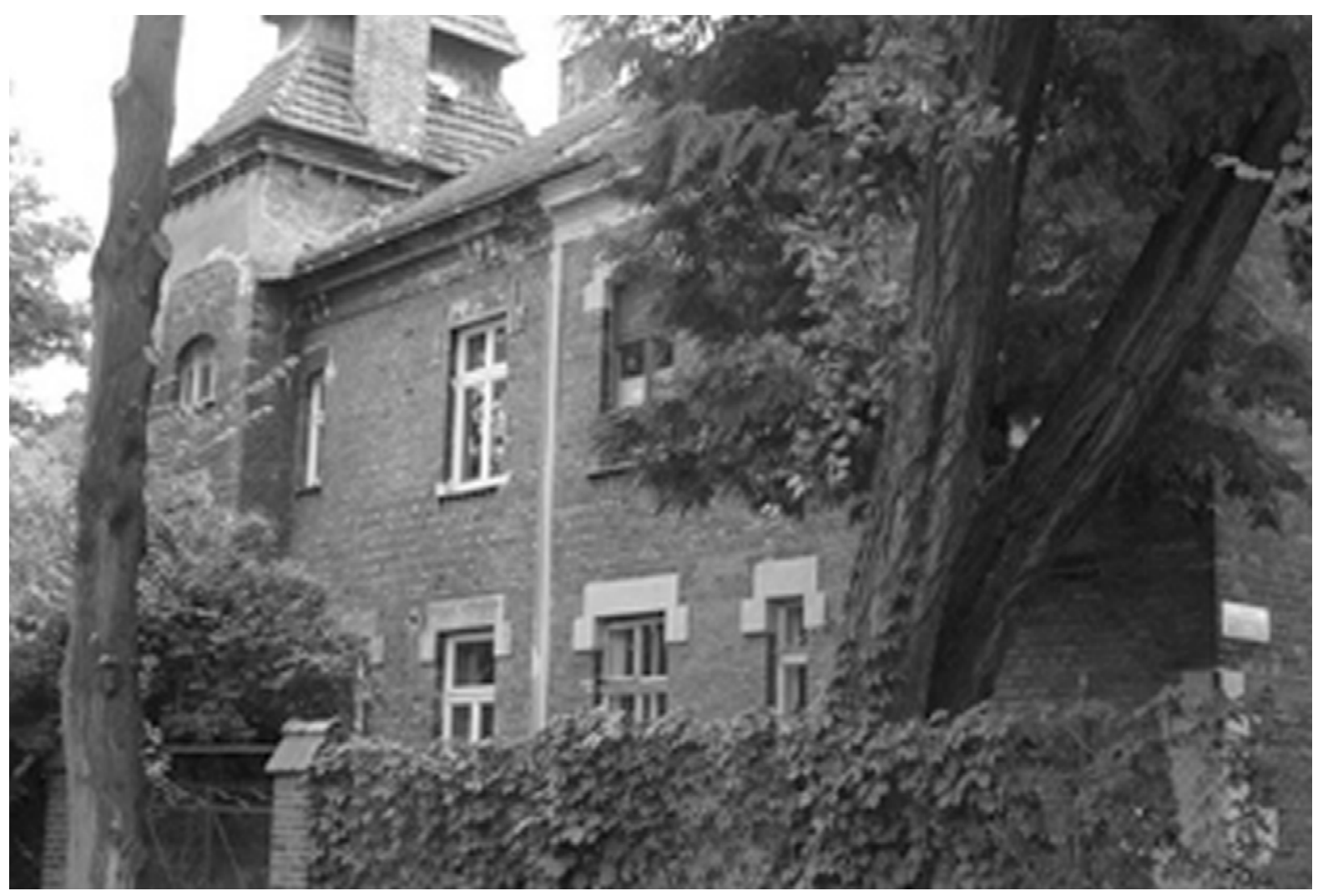

Fig. 5 One of suburban villas at Salwator in Kraków [34] among trees, shrubs and creepers. 
Due to the link with Far Eastern art, which became an inspiration during the turn of the centuries, many plants stirred up people's curiosity, e.g. Narcissus, Paeonia and Chrysanthemum [2,17,20] (Tab. 2).

Willy Lange and Jens Jansen belonged to the landscape architects who, by introducing only native species adequate to a certain place in the garden, propagated the idea of preserving the character of the local landscape in the park or in the garden. Around the house, a formal arrangement was used and it opened out into vast meadows bordering with orchards, e.g. wild apple trees, forests or lakes $[13,14]$.

In Poland native species, such as Bellis perennis, Delphinium elatum, Galanthus nivalis, Crocus vernus, Convallaria majalis, Campanula or Ranunculus repens, were used in newly established gardens. Among the newly introduced bedding plants used in gardens, there were species from South and Central America, Canna indica valued for its large number of hybrids with various colors of flowers and leaves, large-flowered Viola tricolor maxima hort., Salvia splendens and its cultivars. Large-flowered Chrysanthemum originated from Japan (introduced into Polish gardens in 1897) and Lilium regale imported from China [17] were highly appreciated. New cultivars of Iris, Hemerocallis, Lilium, Phlox, Aquilegia, Delphinium [21], Nymphaea, and Lupinus [22] were continuously bred.

\section{Trees}

Trees were often used in garden arrangements in Art Nouveau, a variety of plants including native and foreign species already known in landscaped gardens [22]. Among them there were Tilia, Betula, Quercus, Fagus, Populus, Picea, Abies, Fraxinus, Acer, Larix or Liriodendron tulipifera, Ginkgo biloba, Robinia pseudoacacia, Juglans nigra, Magnolia acuminata, Pinus strobus, Aesculus hippocastanum or Platanus $\times$ hispanica. Hanging plants were also appreciated, e.g. Fraxinus silvatica 'Pendula' [17].

An example of usage of various species of trees is a Secession garden in La Pobla de Lillet in Spain designed by Antonio Gaudi for Joan Artigas. It is situated on the two banks of the Llobregat River, next to a textile factory [23]. The main attraction of the garden is water and the species characteristic of this mountainous region - Pinus, Abies, Quercus, Fagus, Juniperus and Rhododendron [24,25]. To diversify the range of plants, Antonio Gaudi brought palm trees from Park Güell. They became a part of the garden after acclimatization [26].

Trees could be densely planted in small private gardens. They were to create a "slightly dim" impression, adequate for the "melancholic autumn-winter atmosphere" that characterized Art Nouveau [9] (Fig. 6). As a result, in the garden at 25 Studencka Street in Kraków trees such as Platanus $\times$ hispanica, two Tilia and one Fraxinus were planted on a plot of $400 \mathrm{~m}^{2}$ (Fig. 7). Trees appear in city squares, parks and along streets. The best example is Aesculus hippocastanum trees growing along Washington Avenue in Kraków, which links the Art Nouveau housing estate Salwator with Kosciuszko Mound [27], or Tilia trees in Henryk Sienkiewicz Avenue and Polish Army Street in Słupsk. Due to their abundant flowering and reference to the art of the Far East many fruit trees, like apple, pear and cherry trees, were in demand $[2,16]$.

\section{Shrubs}

Shrubs were as important plant material in gardens as trees. In the early twentieth century, new species were introduced. They were characterized by their distinctive

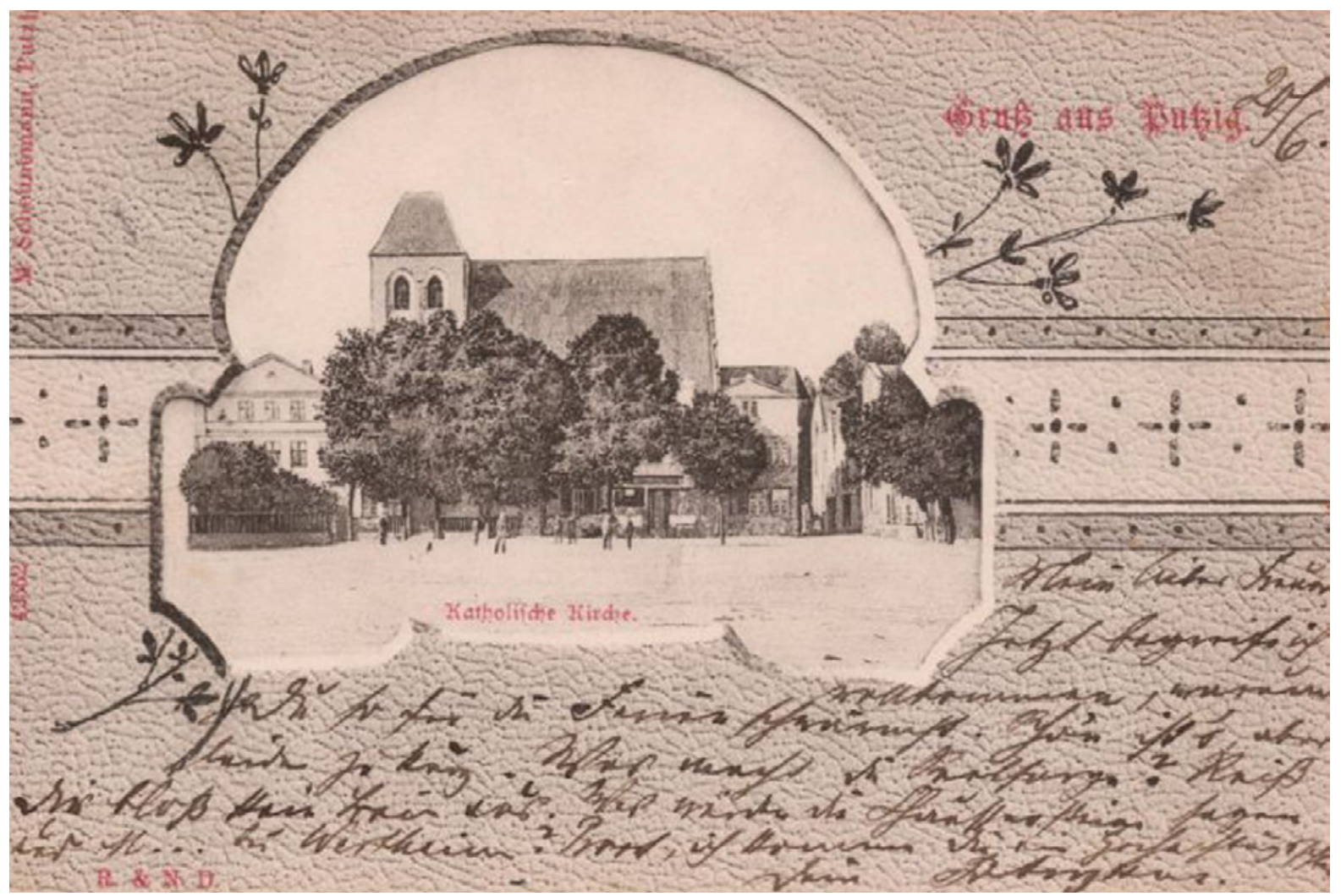

Fig. 6 City square in Puck planted with lindens - postcard from 1903 [35]. 


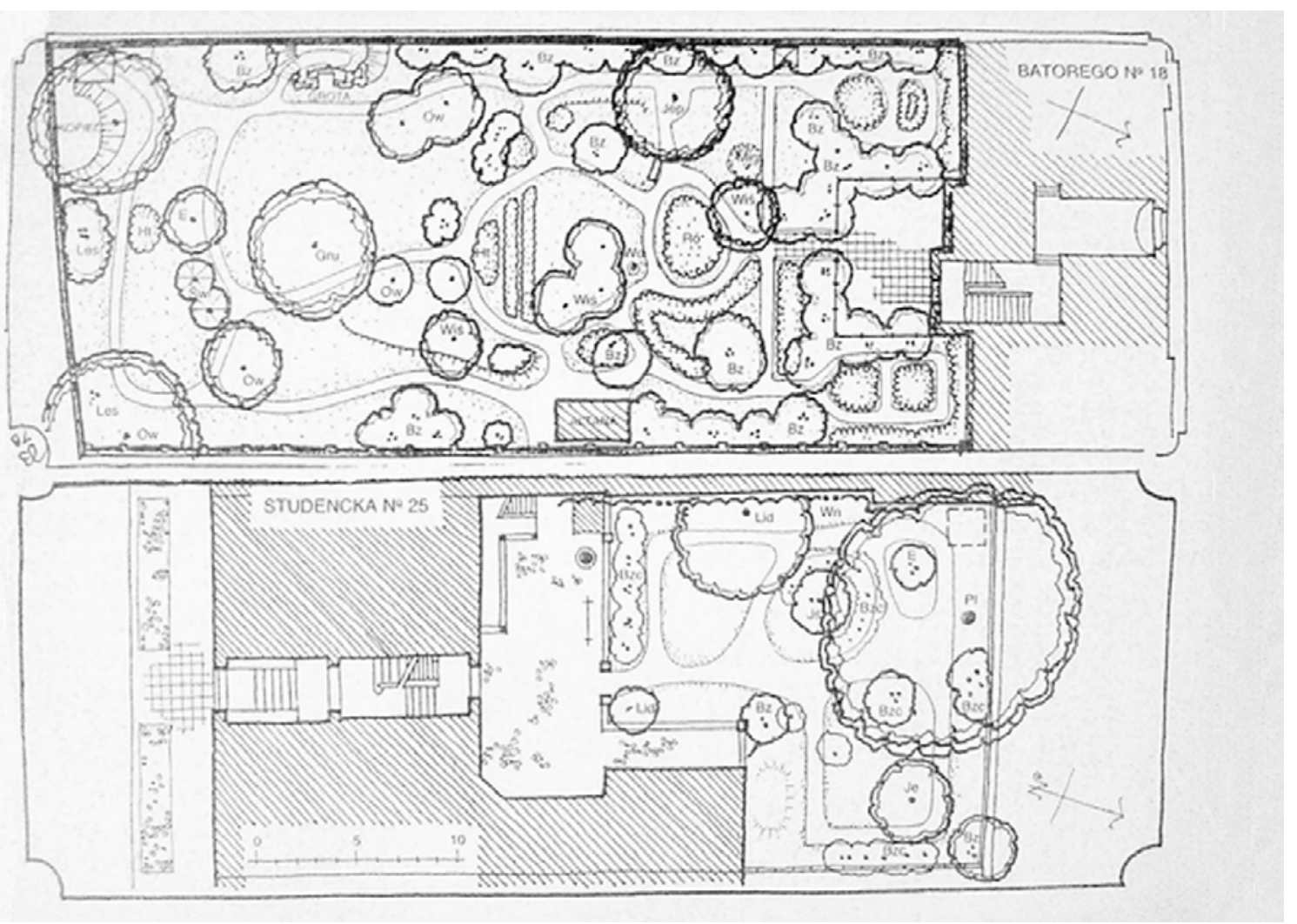

Fig. 7 Art. Nouveau gardens at Batory Street and Studencka Street, Kraków. Various plants are planted on a relatively small plot: Syringa, Sambucus nigra, Pyrus, Hydrangea, Fraxinus, Caragana, Corylus, Tilia, Juglans regia, Platanus $\times$ hispanica, Rosa, Prunus, Malus, Parthenocissus [18].

shape and greater resistance to weather conditions. The new species with the unique characteristics of shoots, leaves, flowers, and fruit as well as diverse flowering periods were especially highly valued. The most important were as follows: Berberis thunbergii, Philadelphus lemoinei, Philadelphus virginalis, Pyracantha coccinea, and Viburnum carlesii [14]. Popular ones included Lonicera tatarica, Rhus typhina, Physocarpus opulifolius, Potentilla fruticosa, Prunus triloba, Hydrangea arborescens, Cotoneaster lucida [17,28] (Tab. 3), and some other ones known much earlier: Ligustrum, Philadelphus, Corylus colurna or Syringa vulgaris (treated as domesticated).

A constant search for new cultivars resulted in introducing many new species of roses. In 1910 a large-flowered rose (Rosa hybrida Polyantha) and in 1904 a new cultivar of Lambert's rose (Rosa lambertiana) were developed. Both species were characteristic of that period [17].

An example of a typical Art Nouveau garden next to a suburban villa is the one in Kraków at 18 Batory Street. The garden is filled with a large number of Syringa vulgaris shrubs. They surround a small terrace connecting the building with the garden. Planted in a row, right next to the fence, they create a "green wall" that shields the space, while further from the building they are planted in groups. The representative space on the axis of the building is occupied by a rose bed and large groups of Hydrangea and Corylus grow among fruit trees (Fig. 7).

\section{Summary}

Despite its short duration, Art Nouveau is remembered as a time of increased interest in nature. In those days, many species gained in popularity and became an inspiration in painting, graphics, applied arts, architecture, and the garden art. Plants with flexible corrugated shapes, straight stems or original flowers enjoyed a special interest. Vines were widely appreciated and broadly implemented, especially in urban spaces. Buildings, terraces, and balconies covered with creepers became a symbol of Art Nouveau. The new trend drew the public's attention to perennials, bulbous plants, and tubers. In gardens, in addition to already known species, new ones were imported from different parts of the world. Efforts were focused on the popularization of plants with extraordinary features such as shape, length of flowering, and color. Trees played a significant part in garden arrangements. The unique light and shadow effects created by their foliage were recognized by the Art Nouveau artists. They were used in small gardens as well as in creating urban parks and alleys. Shrubs were characterized by a variety of species. They were often planted in large groups, which enhanced their decorative values and emphasized the intimate character of the gardens.

The Art Nouveau period did not lead to adopting any specific composition by the next generations, but it left many interesting examples of gardens where the richness of plants can be seen. In Europe and the USA regional 
Tab. 3 Species of trees and shrubs planted in landscape gardens and Art Nouveau gardens $[17,18,36]$.

\begin{tabular}{|c|c|c|}
\hline Latin plant name & Origin & $\begin{array}{l}\text { Landscape architect, } \\
\text { popularizer of species }\end{array}$ \\
\hline Aesculus hippocastanum L. & Balkan Peninsula & $\begin{array}{l}\text { Robinson W., Jekyll G., } \\
\text { Lutyens E. }\end{array}$ \\
\hline Cotinus coggygria Scop. & Asia & Olmsted F.L., Farrand B. \\
\hline Ginkgo biloba L. & China & Robinson W., Olmsted F.L. \\
\hline Hydrangea arborescens $\mathrm{L}$. & North America & $\begin{array}{l}\text { Olsson P., Lutyens E., } \\
\text { Farrand B., Crawley G. }\end{array}$ \\
\hline Liriodendron tulipifera L. & North America & Olmsted F.L., \\
\hline Lonicera tatarica $\mathrm{L}$. & Europe, Asia & Robinson W., \\
\hline Magnolia acuminata L. & North America & $\begin{array}{l}\text { Olmsted F.L., Jekyll G., } \\
\text { Lutyens E. }\end{array}$ \\
\hline Pinus strobus L. & North America & $\begin{array}{l}\text { Gaudi A., Olmsted F.L., } \\
\text { Olsson P., Farrand B., } \\
\text { Crawley G. }\end{array}$ \\
\hline Potentilla fruticosa $\mathrm{L}$. & North America & Gaudi A., \\
\hline Prunus triloba Lindl. & China & $\begin{array}{l}\text { Jekyll G., Lutyens E., Farrand } \\
\text { B. }\end{array}$ \\
\hline palms & Asia, Africa, South America & Gaudi A., Thomas I., \\
\hline Rhus typhina L. & North America & Robinson W., \\
\hline $\begin{array}{l}\text { Wisteria sinensis (Sims) } \\
\text { Sweet. }\end{array}$ & North America & $\begin{array}{l}\text { Olsson P., Lutyens E., } \\
\text { Farrand B., Crawley G. }\end{array}$ \\
\hline
\end{tabular}

variations of Secession developed. In Poland its influence can be found among the tenements, shaded alleys or suburban villas "immersed in the greenery". These are also examples

\section{Acknowledgments}

The study was supported by University of Life Sciences in Lublin.

\section{Authors' contributions}

The following declarations about authors' contributions to the research have been made: concept of the study: KP; research: AM, KP; writing: KP, AM.

\section{Competing interests}

No competing interests have been declared.

\section{References}

1. Kubalska-Sulkiewicz K, editor. Słownik terminologiczny sztuk pięknych wyd. V. Warszawa: PWN; 2005.

2. Wallis M. Secesja. Warszawa: Wyd. Arkady; 1984.

3. Estreicher K. Historia sztuki w zarysie. 7th ed. Warszawa: PWN; 1986.

4. Pękala T. Secesja: konkretyzacje i interpretacje. Lublin: Wydawnictwo Uniwersytetu Marii Curie-Skłodowskiej; 1995.

5. Zachariasz A. Ogród modernistyczny - przemiany formy. In: Gawryszewska BJ, Rothimel B, editors. Ogród za oknem w poszukiwaniu formy. Warszawa: Wyd. Sztuka ogrodu Sztuka krajobrazu; 2009. p. 24-32.

6. Ormiston R, Robinson M. Secesja: plakat, ilustracja książkowa i malarstwo czarującej epoki fin de siecle’u. Warszawa: Wyd. Arkady; 2010.

7. de la Bédoyère C. Secesja. Warszawa: Wyd. Arkady; 2007.

8. Zerbst R. Antoni Gaudi: wszystkie budowle. Köln: Taschen; 2004.

9. Ciołek G. Ogrody polskie. Warszawa: Wyd. Arkady; 1978.

10. Okoń W. Stanisław Wyspiański. Wrocław: Wyd. Dolnośląskie; 2001. of Edwardian gardens of the later period - a combination of plants growing inside the "architectural" garden with an axial arrangement.

11. Siewniak M, Mitkowska A. Tezaurus sztuki ogrodowej. Warszawa: Oficyna Wydawnicza RYTM; 1998.

12. Bogdanowski J. Style, kompozycja i rewaloryzacja w polskiej sztuce ogrodowej. Wiad Bot. 1992;36(3-4):3-16.

13. Hobhouse P. Historia ogrodów. Warszawa: Wyd. Arkady; 2005.

14. Majdecki L. Historia ogrodów. Warszawa: Wyd. PWN, 2010. (vol 2).

15. Trzaskowska E. Wykorzystanie roślin w projektowaniu architektonicznym (pnącza, ogrody wertykalne. Teka Komisji Architektury, Urbanistyki i Studiów Krajobrazowych O.L. PAN. 2010;6:110-121.

16. Makowska B. Motywy roślinne w dekoracjach krakowskich kamienic z przełomu XIX/XX wieku. Wiad Bot. 2005;49(3-4):5-14.

17. Majdecki L. Konserwacja zabytkowych założeń ogrodowych. Warszawa: Wyd. PWN; 1993.

18. Bogdanowski J. Polskie ogrody ozdobne: historia i problemy rewaloryzacji. Warszawa: Arkady; 2000.

19. Ormiston R. William Morris: artist, craftsman, pioneer. London: Flame Tree Publishing; 2010.

20. Stępniewska B. Tendencje kształtowania zieleni w wiekach XIX i XX w Europie. Wrocław: Oficyna Wydawnicza Politechniki Wrocławskiej; 1996.

21. Różańska A. Historia europejskiej sztuki ogrodowej. In: Różańska A, Krogulec T, Rylke J, editors. Ogrody. Historia architektury i sztuki ogrodowej. Warszawa: Wyd. SGGW; 2008. p. 117-123.

22. Furmanik B. Dobory materiałowe w ogrodach zabytkowych. Kurier konserwatorski. 2010;7:23-31.

23. Zerbst R. Gaudí 1852-1926: Antoni Gaudí i Cornet: życie dla architektury. Köln: Taschen; 1992. 
24. Alt Bergueds. Serra del Catllaràs [Internet]. 2013 [cited 2013 Jun 17]; Available from: http://www.altbergueda.cat/en/pl14/id354/ Llocs_dinteres/Natura/serra-del-catllaras.htm

25. Antonigaudi. Gaudí. El hombre y su obra [Internet]. 2013 [cited 2013 Jun 17]; Available from: http://www.antonigaudi.org/Eng/30/364/1. htm

26. Gencat. Parcs naturals [Internet]. 2013 [cited 2013 Jun 17]; Available from: http://www20.gencat.cat/portal/site/parcsnaturals/menuitem. 93512201aa2411c0e6789a10b0c0e1a0/?vgnextoid=e4a3b10378a3221 0VgnVCM1000008d0cle0aRCRD\&vgnextchannel=e4a3b10378a32 210VgnVCM1000008d0cle0aRCRD\&vgnextfmt=default

27. Brückman de Renstrom K. Salwator, Kraków, Europa. Historia i architektura osiedla (1908-2003) na tle przemian w architekturze krakowskiej i europejskiej początku XX wieku. Kraków: Wyd. PK; 2003.

28. Erhardt W, Götz E, Bödeker N, Sybold S. Zander: Handwörterbuch der Pflanzennamen (Dictionary of plant names). Stuttgart: Eugen Ulmer; 2008.

29. Fahr-Becker G. Secesja (Art Nouveau). Königswinter: Konemann; 2004.

30. Forstner D. Świat symboliki czhrześcijańskiej Leksykon (Die Welt der christlichen Symbole). Warszawa: Instytut Wydawniczy PAX; 2001.

31. Włodarczyk Z. Rośliny biblijne Leksykon. Kraków: Instytut Botaniki im. W. Szafera Polskiej Akademii Nauk; 2011.

32. Lehr U. Plants as magic apotropaic means in Polish folk demonology and magic. In: Paluch A, editor. Ethnobotany. Proceedings of 1st Polish ethnobotanic seminar Kolbuszowa 19-20 July 1980. Kolbuszowa: University of Wrocław; 1985. p. 57-82.
33. Impelluso L. Natura i jej symbole: rośliny i zwierzęta. Warszawa: Arkady; 2006.

34. skyscrapercity [Internet]. 2013 [cited 2013 Jun 17]; Available from: http://www.skyscrapercity.com/showthread.php?t=481153\&page $=14$

35. Historia. Skarby Kaszub [Internet]. 2013 [cited 2013 Jun 17]; Available from: http://historia.skarbykaszub.pl/displayimage.php?pid=1846

36. Holmes C. Gartenkunst/Icons of Garden. Bartelsmann Media. Horyzont; 2002.

\section{Bogactwo flory w ogrodach secesji}

\section{Streszczenie}

Przełom XIX i XX wieku wyznacza pojawienie się nowego nurtu w sztuce nazywanego w Anglii Art Nouveau, we Włoszech Stile floreale, a w Polsce secesją. Był próbą zerwania ze stylem naśladującym historyczne formy i nakreśleniem nowego kierunku rozwoju. Główną inspiracją dla twórców tego okresu stała się natura, jej asymetria, różnorodność faktur, subtelność kolorów, płynna, falista linia. Motywy artystyczne czerpano przede wszystkim z bogactwa fauny i rodzimej flory. Zwłaszcza kwitnące krzewy, byliny, pnącza były jednym z nieodłącznych elementów zdobniczych i kompozycyjnych.

Secesja wywarła wpływ na malarstwo, rzeźbę, architekturę oraz sposób kreacji ogrodów. Przestrzeń otaczająca człowieka była traktowana całościowo poprzez zacieranie granic między poszczególnymi dziedzinami sztuki. Mnogość, krzewów - zwłaszcza krzewów róży i duży udział bylin, takich jak lilie, irysy, floksy, stwarzały wrażenie stapiania się architektury $\mathrm{z}$ otaczającym ogrodem.

Celem pracy jest krótka analiza secesyjnej stylistyki i na jej tle prezentacja różnorodności gatunków wykorzystywanych w ogrodach tego okresu. 